www.nature.com/ejcn

\title{
OBITUARY
}

\section{Professor Graham L Hill}

European Journal of Clinical Nutrition (2013) 67, 687; doi:10.1038/ejcn.2013.94

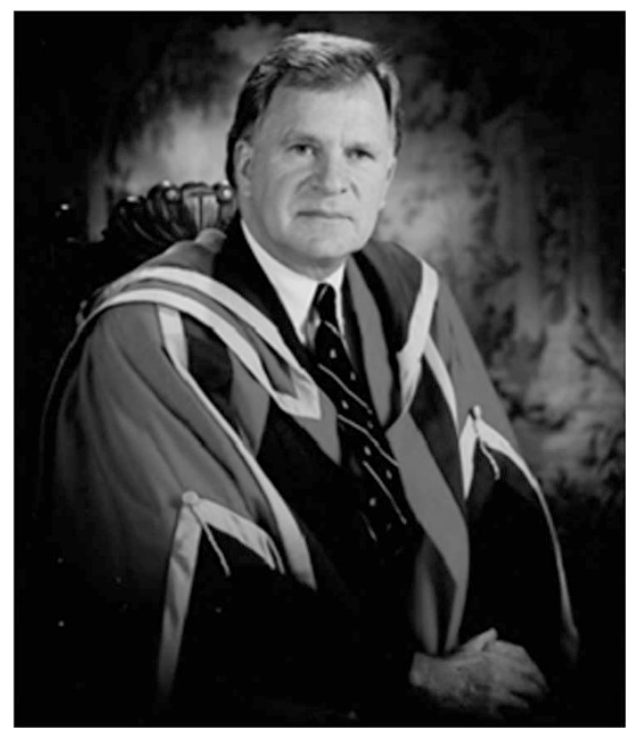

Professor Graham L Hill, 1939-2013.

Emeritus Professor of Surgery at the University of Auckland, Graham Hill, died in Dunedin, New Zealand, on 28 February after a prolonged illness.

It was in Dunedin at the University of Otago where Graham completed his early medical education and where, as a trainee surgeon in 1968, he met Francis (Franny) Moore. Dr Moore was the inspiration behind Graham's decision to pursue an academic surgical career. After a period as a missionary surgeon in Indonesia, Graham spent a year in John Goligher's world-leading Department of Surgery at the General Infirmary at Leeds, renowned for its expertise in colorectal surgery. He returned to the University of Leeds as a Reader in Surgery after 2 years with Stanley Dudrick in Houston, and it was at Leeds where he realized the potential of the neutron activation technique for assessing body protein metabolism in illness. In 1980, he took up the Chair in Surgery at the University of Auckland and set about establishing a unique facility capable of measuring the detailed body composition of critically ill patients.

Graham's first published paper in The Lancet (1967) set the standard for more than 200 published papers and 35 book chapters to follow. With these, and a splendid monograph, 'Disorders of Nutrition and Metabolism in Clinical Surgery', he made significant contributions to our understanding of surgical nutrition and metabolism.

He facilitated the training of numerous surgical registrars who were privileged to observe his outstanding surgical skills. More than 30 full-time research fellows came under Graham's tutelage inspired by a genuine and infectious enthusiasm for research and his penetrating insights in the area of surgical metabolism. Graham's lectures, whether to an undergraduate class or to an international forum, were models of clarity and lucidity, and will be remembered by former students and professionals alike. Graham's love of and commitment to research led to significant innovations in colorectal surgery. Establishing the first colorectal unit in New Zealand, he delivered a national service for patients with complex colorectal disease. His patients remember the gentle and reassuring bedside manner that made them feel important and special.

The recipient of numerous international awards and distinguished visiting professorships, Graham served on the Editorial Boards of many surgical and clinical nutrition journals. Honoured as both the ASPEN Jonathan E. Rhoads lecturer (in 1992) and the ESPEN Sir David Cuthbertson lecturer (in 1994) was a rare distinction shared only by Franny Moore and four others from North America. 